\title{
Orphanin FQ inhibits capsaicin-induced thermal nociception in monkeys by activation of peripheral ORL1 receptors
}

\author{
${ }^{*, 1}$ M.C.H. Ko, ${ }^{2}$ N.N. Naughton, ${ }^{1}$ J.R. Traynor, ${ }^{1}$ M.S. Song, ${ }^{1}$ J.H. Woods, ${ }^{3}$ K.C. Rice \& \\ ${ }^{4}$ A.T. McKnight
}

${ }^{1}$ Department of Pharmacology, University of Michigan Medical School, Ann Arbor, Michigan, U.S.A.; ${ }^{2}$ Department of Anesthesiology, University of Michigan Medical School, Ann Arbor, Michigan, U.S.A.; ${ }^{3}$ Laboratory of Medicinal Chemistry, National Institute of Diabetes and Digestive and Kinney Diseases, National Institutes of Health, Bethesda, Maryland, U.S.A. and ${ }^{4}$ Oxford Natural Products, Charlbury, Oxfordshire

1 Orphanin FQ (OFQ), an endogenous peptide for ORL1 receptors, has been identified. Although the actions of OFQ have much in common with those of opioid peptides at the cellular level, behavioral studies in rodents seem conflicting.

2 The aim of this study was to investigate the potential pronociceptive or antinociceptive function of peripheral ORL1 receptors in primates. Experiments were conducted to verify whether local administration of OFQ can attenuate capsaicin-induced nociception and whether peripheral ORL1 receptors selectively mediate the local action of OFQ in monkeys.

3 Capsaicin $(100 \mu \mathrm{g})$ was administered subcutaneously in the tail to locally evoke a nociceptive response (thermal allodynia/hyperalgesia), which was manifested as a reduced tail-withdrawal latency in normally innocuous $46^{\circ} \mathrm{C}$ warm water.

4 Co-administration of OFQ $(1-30 \mu \mathrm{g})$ with capsaicin in the tail dose-dependently inhibited thermal nociception. However, a locally effective dose of OFQ $(30 \mu \mathrm{g})$, when applied in the back, did not inhibit capsaicin-induced nociception.

5 OFQ-induced local antinociception was antagonized by a small dose (10 $\mu \mathrm{g})$ of J-113397, a selective ORL1 receptor antagonist, in the tail. Similarly, s.c. administration of $10 \mu \mathrm{g}$ of J-113397 in the back did not antagonize local antinociception of OFQ.

6 In addition, s.c. administration of either OFQ or J-113397 in the tail alone did not change its thermal nociceptive threshold. Local administration of opioid receptor antagonists selective for mu, kappa, and delta opioid receptors did not antagonize OFQ-induced local antinociception. Local administration of J-113397 also did not interfere with the local actions of mu, kappa, and delta opioid agonists in the tail.

7 These results provide the first functional evidence that activation of peripheral ORL1 receptors produces thermal antinociception in primates and this action is independent of antinociception produced at classical opioid receptors.

British Journal of Pharmacology (2002) 135, 943-950

Keywords: Antinociception; orphanin FQ; ORL1 receptors; capsaicin; peripheral tissues; primary afferent nociceptors; hyperalgesia

Abbreviations: capsaicin, 8-methyl-N-vanillyl-6-nonenamide; $\delta \mathrm{OR}$, delta opioid receptors, $\kappa$ OR: kappa opioid receptors, $\mu \mathrm{OR}$ : $m u$ opioid receptors, nor-BNI: nor-binaltorphimine; OFQ, Orphanin FQ; \%MPE, per cent of maximum possible effect

\section{Introduction}

Orphanin FQ (OFQ) is a heptadecapeptide that is an endogenous ligand for orphan opioid receptor-like (ORL1) receptors (Mollereau et al., 1994; Meunier et al., 1995; Reinscheid et al., 1995). The ORL1 receptor is highly homologous with classical opioid receptors, particularly in its transmembrane and intracellular domains. Unlike opioid receptors, the ORL1 receptor does not bind opioid ligands with high affinity. For example, classical opioid receptor agonists and antagonists, such as morphine and naloxone, are not active on the ORL1 receptor (see reviews, 'Henderson \&

*Author for correspondence at: Department of Pharmacology, University of Michigan Medical School, 1301 MSRB III, Ann Arbor, MI 48109-0632, U.S.A.; E-mail: mko@umich.edu
McKnight, 1997; Darland et al., 1998; Calo et al., 2000). Although the actions of OFQ have much in common with those of opioid peptides at the cellular level, functional studies suggest high degree of complexity. Pharmacological studies in rodent species have shown a dual activity of OFQ (i.e., both pronociceptive and antinociceptive actions) in pain modulation, depending on several factors including administration routes, dose ranges and nociceptive assays (Calo et al., 2000). However, it is unknown whether activation of ORL1 receptors by OFQ in primates produces pronociceptive or antinociceptive effects.

OFQ inhibits cyclic AMP accumulation (Meunier et al., 1995; Reinscheid et al., 1995), inhibits $\mathrm{Ca}^{2+}$ entry through voltage-dependent $\mathrm{Ca}^{2+}$ channels (Connor et al., 1996; 
Knoflach et al., 1996), and increases $\mathrm{K}^{+}$conductance in neurons (Vaughan \& Christie, 1996; Jennings, 2001). In addition, it has been shown that OFQ inhibits the release of pronociceptive substances such as substance $P$ (SP) and calcitonin gene-related peptide (CGRP) from peripheral sensory nerves (Giuliani \& Maggi, 1996; 1997). These in vitro studies seem to support the inhibitory function of the ORL1 receptor in the nociception-relevant processes.

Capsaicin, the pungent ingredient in hot chili peppers, has been used to evoke nociception for evaluating potential antinociceptive agents in monkeys and humans (Eisenach et al., 1997; Ko et al., 1998). Exposure of primary afferent nociceptors to capsaicin leads to excitation of the neuron and local release of inflammatory pain mediators such as SP and CGRP (see reviews, Winter et al., 1995; Szallasi \& Blumberg, 1999). It has been reported that intradermal administration of capsaicin to human skin produces burning pain and allodynic/hyperalgesic responses (Simone et al., 1989; Lamotte et al., 1992). We also found that s.c. administration of capsaicin in the monkey's tail evoked a nociceptive response, thermal allodynia/hyperalgesia, which was manifested as a reduced tail-withdrawal latency in normally innocuous warm water (Ko et al., 1998). In this procedure, s.c. administration of small, systemically inactive doses of $m u$ opioid receptor $(\mu \mathrm{OR})$ agonists or kappa opioid receptor $(\kappa \mathrm{OR})$ agonists in the tail can attenuate capsaicin-induced thermal nociception. This local antinociception has been demonstrated as the function of peripheral opioid receptors and it can be pharmacologically separated from the central action of opioids (Ko et al., 1998; 1999a, b). More importantly, this capsaicin-induced pain model in monkeys provides a useful tool to study the peripheral antinociception of novel agents, which may have the therapeutic potential in humans.

The aim of this study was therefore to examine whether local administration of OFQ can attenuate capsaicin-induced nociception in monkeys. Antagonist studies were performed to confirm whether the ORL1 receptor mediates the peripheral action of OFQ by using a selective ORL1 receptor antagonist, J-113397 (Kawamoto et al., 1999; Ozaki et al., 2000). In addition, selective opioid agonists and antagonists were used in this procedure to evaluate whether the function of peripheral ORL1 receptors is independent of classical opioid receptors.

\section{Methods}

\section{Subjects}

Six adult male and female rhesus monkeys (Macaca mulatta) with body weights ranging between 7.6 and $12.9 \mathrm{~kg}$ were used (their mean weight during this study was $9.8 \mathrm{~kg}$ ). Individual weight did not significantly change throughout the entire study. They were housed individually with free access to water and were fed approximately 25-30 biscuits (Purina Monkey Chow; Ralston Purina Co., St. Louis, MO, U.S.A.) and fresh fruit daily. All monkeys were previously trained in the warm water tail-withdrawal procedure and they did not have exposure to any drug including opioids or capsaicin for one month before the present study. Animals used in this study were maintained in accordance with the University Committee on the Use and Care of Animals in the University of Michigan, and the Guide for the Care and Use of Laboratory Animals (7th edn) by the Institute of Laboratory Animal Resources (Natl. Acad. Press, Washington DC, revised 1996).

\section{Procedure}

Nociceptive responses to thermal stimuli were measured by a warm water tail-withdrawal procedure which has been described previously (Ko et al., 1998). Briefly, monkeys were seated in restraint chairs and the lower part of the shaved tail, approximately $15 \mathrm{~cm}$, was immersed into warm water maintained at temperatures of 42,46 , or $50^{\circ} \mathrm{C}$. Tail-withdrawal latencies were measured by an experimenter who did not know the experimental conditions. A maximum cutoff latency, $20 \mathrm{~s}$, was used. Each experimental session began with control determinations at three temperatures in a varying order. Subsequent tail-withdrawal latencies were determined at 5, 15, 30, 45, and $60 \mathrm{~min}$ after the drug injection. A single dosing procedure was used in all test sessions. All six monkeys were used in each experimental session which was conducted once per 10 days.

\section{Experimental design}

After capsaicin was administered subcutaneously in the tail, it dose-dependently caused thermal nociception. This thermal nociception, allodynic/hyperalgesic response, was manifested as a reduced tail-withdrawal latency, from a maximum value of $20 \mathrm{~s}$ to approximately $2-3 \mathrm{~s}$, in $46^{\circ} \mathrm{C}$ water at $15 \mathrm{~min}$ after injection. The 15 min time point was the time of peak effects of capsaicin because there was no temperature- and capsaicin dose-dependency at the $5 \mathrm{~min}$ time point and there was a lesser degree of capsaicin effects at the $30 \mathrm{~min}$ and remaining time points (Ko et al., 1998). In addition, $46^{\circ} \mathrm{C}$ water was chosen because there was a lesser degree of thermal allodynia/hyperalgesia in $42^{\circ} \mathrm{C}$ water and it was not possible to study hyperalgesic responses in $50^{\circ} \mathrm{C}$ water after capsaicin (Ko et al., 1998). Based on these previous results, we choose $100 \mu \mathrm{g}$ of capsaicin in $46^{\circ} \mathrm{C}$ water as a standard noxious stimulus to evoke thermal allodynia/hyperalgesia for the present study.

\section{Antinociceptive effects of orphanin FQ}

OFQ $(1-30 \mu \mathrm{g})$ was co-administered with capsaicin in the tail to evaluate its antinociceptive effect. After the doseresponse study, the maximum locally effective dose was administered subcutaneously in the back (i.e., around the scapular region), in order to verify the local action of OFQ. In addition, this locally effective dose was administered subcutaneously in the tail alone to evaluate whether it changed the thermal nociceptive threshold in the absence of capsaicin.

\section{Antagonism of peripheral ORL1 receptors}

Considering that onset and distribution factors may be minimized with local administration, J-113397 $(1-10 \mu \mathrm{g})$, a selective ORL1 receptor antagonist, was co-administered with capsaicin and OFQ in the tail to evaluate its local antagonist effect. Similarly, the maximum locally effective dose of $\mathrm{J}$ - 
113397 was injected subcutaneously in the back to verify whether its ORL1 receptor antagonism was localized in the tail. The locally effective dose of J-113397 was also administered in the tail alone to detect whether it changed the thermal nociceptive threshold of the monkey's tail.

In addition, three opioid receptor antagonists, quadazocine, nor-binaltorphimine (nor-BNI), and naltrindole, which are selective for $\mu \mathrm{OR}, \kappa \mathrm{OR}$, and $\delta \mathrm{OR}$, respectively, were used to confirm the receptor selectivity of OFQ $(30 \mu \mathrm{g})$-induced local antinociception. It has been demonstrated that $10 \mu \mathrm{g}$ of quadazocine and $320 \mu \mathrm{g}$ of nor-BNI significantly antagonized $\mu \mathrm{OR}$ agonist- and $\kappa \mathrm{OR}$ agonist-induced local antinociception respectively in our previous studies (Ko et al., 1998; 1999a; 2000). We previously found that local administration of BW373U86, a selective $\delta$ OR agonist, in the tail did not attenuate capsaicin-induced thermal nociception (unpublished data). Thus, it is difficult to determine the locally active dose of naltrindole in the monkey's tail. The large dose of naltrindole $320 \mu \mathrm{g}$ was chosen based on its systemically active dose, $1 \mathrm{mg} \mathrm{kg}^{-1}$, in monkeys (Butelman et al., 1995). This dose for local injection in the tail was approximately 30 fold lower than systemic dose in the monkeys weighing $10 \mathrm{~kg}$. Furthermore, three opioid receptor agonists, DAMGO, U50488 and BW373U86, which are selective for $\mu \mathrm{OR}$, $\kappa \mathrm{OR}$, and $\delta \mathrm{OR}$, respectively, were used to verify the ORL1 receptor antagonism selectivity of J-113397. In previous studies, it has been demonstrated that $32 \mu \mathrm{g}$ of DAMGO and $100 \mu \mathrm{g}$ of U50488 significantly attenuated capsaicin $(100 \mu \mathrm{g})$-induced thermal nociception through peripheral $\mu \mathrm{OR}$ and $\kappa \mathrm{OR}$, respectively (Ko et al., 1998; 1999a, b). By using the same procedure, $10 \mu \mathrm{g}$ of $\mathrm{J}-113397$ was coadministered with capsaicin and one opioid receptor agonist in the tail to verify whether J-113397 interfered with the local actions of different types of opioid receptor agonists.

\section{Data analysis}

Individual tail-withdrawal latencies were converted to per cent of maximum possible effect (\%MPE) by the following formula: $\% \mathrm{MPE}=[$ (test latency - control latency) $/$ (cutoff latency, $20 \mathrm{~s}-$ control latency)] $\times 100$, in order to calculate $\mathrm{ED}_{50}$ values. The $15 \mathrm{~min}$ time point was used for data analysis because this was the time of peak effects of capsaicin and peptidic opioid agonists following local administration (Ko et al., 1998; 1999a; 2000). Mean $\mathrm{ED}_{50}$ values were obtained from individual $\mathrm{ED}_{50}$ values, which were calculated by least-squares regression using the portion of the doseeffect curves spanning 50\% MPE, and 95\% confidence limits were also determined. In addition, significant differences of tail-withdrawal latencies between dosing conditions were analysed with one-way ANOVA followed by the NewmanKeuls test $(P<.01)$.

\section{Drugs}

OFQ (NIDA, NIH, Bethesda, MD, U.S.A.), DAMGO and BW373U86 (Sigma, St. Louis, MO, U.S.A.), U50488 (Upjohn Co., Kalamazoo, MI, U.S.A.), quadazocine (Sanofi, Malvern, PA, U.S.A.), nor-BNI (provided by Dr. H.I. Mosberg, Ann Arbor, MI, U.S.A.), naltrindole (NIDDK, NIH, Bethesda, MD, U.S.A.), and J-113397 (Pfizer Global Research and Development, Cambridge, U.K.) were dissolved in sterile water. Capsaicin (Sigma, St. Louis, MO, U.S.A.) was dissolved in a solution of Tween $80 /$ ethanol/saline in a ratio of $1: 1: 8$. All compounds were mixed in the capsaicin solution and were injected subcutaneously in the terminal $1-4 \mathrm{~cm}$ of the tail with constant $0.1 \mathrm{ml}$ volume.

\section{Results}

Monkeys used in this study displayed a consistent profile in tail-withdrawal responses. They kept their tails in 42 and $46^{\circ} \mathrm{C}$ water for $20 \mathrm{~s}$ (cutoff latency) and removed their tails

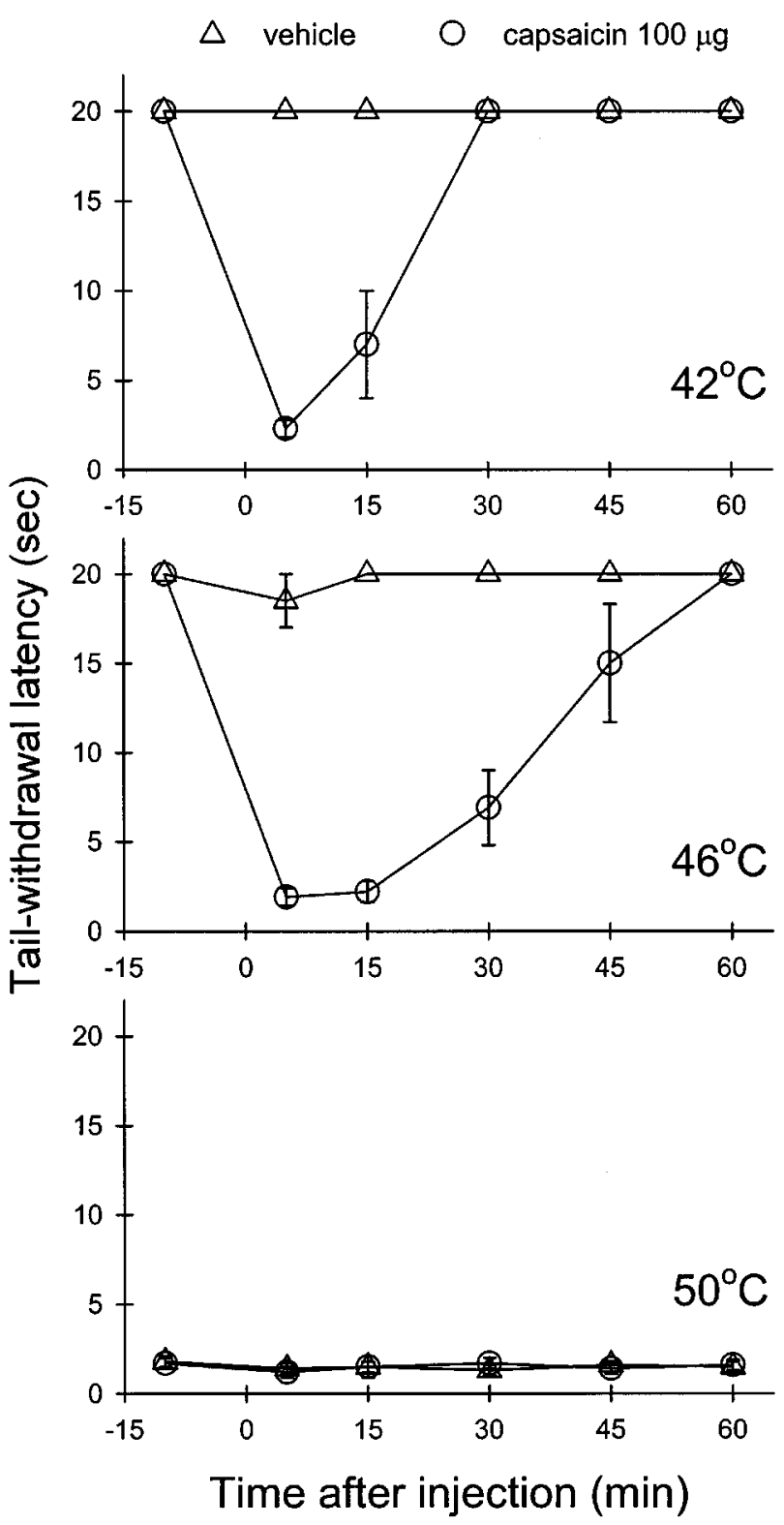

Figure 1 Time course of capsaicin-induced thermal nociception, allodynia/hyperalgesia, in monkeys. Each panel represents the time course of capsaicin effect on the tail-withdrawal latency in different degrees of water. All points represent the mean \pm s.e.m. $(n=6)$. Before injection, the tail-withdrawal latencies were determined. Either capsaicin $100 \mu \mathrm{g}$ or vehicle solution was injected subcutaneously in the tail with constant $0.1 \mathrm{ml}$ volume at ' 0 ' time point. 
from $50^{\circ} \mathrm{C}$ water rapidly (within $1-3 \mathrm{~s}$ ). After capsaicin $100 \mu \mathrm{g}$ was injected subcutaneously in the tail, it evoked a nociceptive response, thermal allodynia/hyperalgesia, which was manifested as a reduced tail-withdrawal latency in $46^{\circ} \mathrm{C}$ water. This thermal nociceptive response started at $5 \mathrm{~min}$, continued until $15 \mathrm{~min}$, and then gradually disappeared within an hour after injection (see Figure 1, middle panel). These responses were similar to those we have reported previously in different groups of monkeys (Ko et al., 1998; 1999a; 2000).

\section{Antinociceptive effects of orphanin $F Q$}

Figure 2 illustrates the antinociceptive effect of OFQ against capsaicin-induced thermal nociception following s.c. administration in the tail. Co-administration of OFQ $(1-30 \mu \mathrm{g})$ with capsaicin $(100 \mu \mathrm{g})$ in the tail dose-dependently attenuated capsaicin-induced thermal nociception in $46^{\circ} \mathrm{C}$ water. However, when the locally effective dose of OFQ $30 \mu \mathrm{g}$ was administered subcutaneously in the back, it was not effective against capsaicin. The $\mathrm{ED}_{50}$ value of OFQ-induced local antinociception in this procedure was $6.3 \mu \mathrm{g}(95 \%$ C.L.: $3.6-$ $11.1 \mu \mathrm{g})$. It is worth noting that s.c. administration of OFQ in the tail and in the back at these doses did not cause any notable behavioral changes, such as sedation or agitation.

\section{Antagonism of peripheral ORL1 receptors}

Figure 3 illustrates the peripheral ORL1 receptor antagonism of OFQ-induced local antinociception by J-113397 in the tail. Co-administration of $\mathrm{J}-113397(1-10 \mu \mathrm{g})$ with capsaicin $(100 \mu \mathrm{g})$ and OFQ $(30 \mu \mathrm{g})$ in the tail dose-dependently antagonized the inhibitory action of OFQ in capsaicininduced nociception in $46^{\circ} \mathrm{C}$ water. However, when the locally effective dose of $\mathrm{J}-113397,10 \mu \mathrm{g}$, was administered

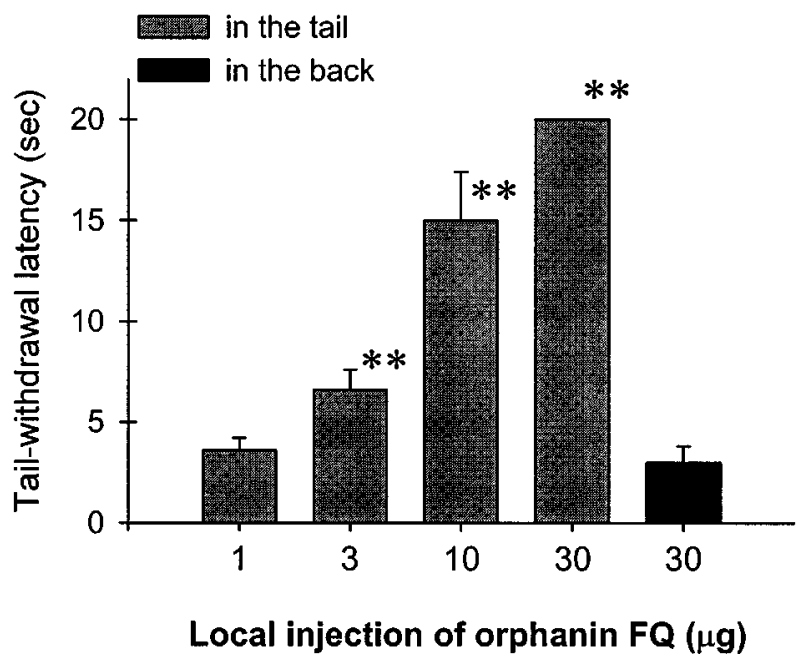

Figure 2 Antinociceptive effects of orphanin FQ against capsaicininduced thermal nociception in $46^{\circ} \mathrm{C}$ water. Filled gray bars indicate that orphanin FQ was co-administered with capsaicin $(100 \mu \mathrm{g})$ in the tail and black bars indicate that orphanin FQ was administered s.c. in the back. Each value represents the mean \pm s.e.m. $(n=6)$. Asterisks represent a significant difference from control, i.e., capsaicin alone $\left({ }^{* *} P<.01\right)$. Abscissae: doses of orphanin FQ. Ordinates: tailwithdrawal latency (s). Each data point was obtained at $15 \mathrm{~min}$ after injection. See Methods for other details.

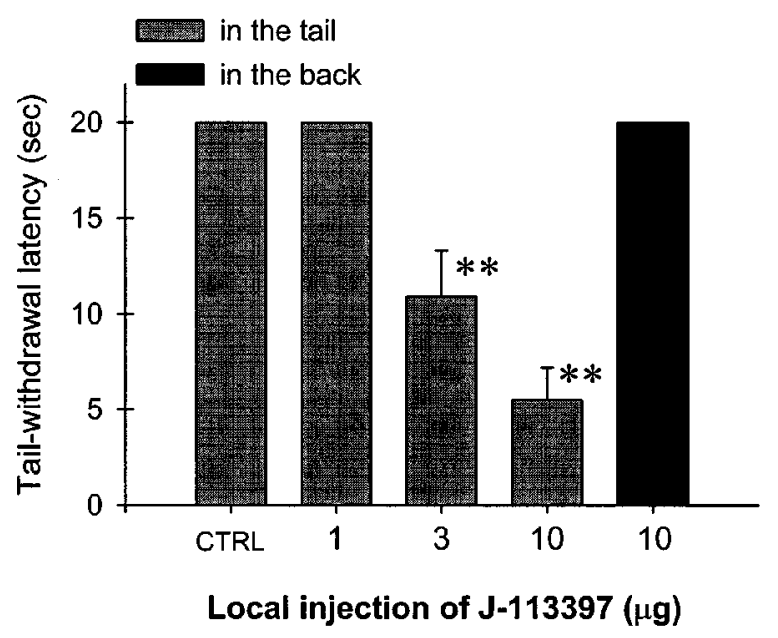

Figure 3 Antagonism of J-113397 in local antinociceptive effects of orphanin $\mathrm{FQ}$ in $46^{\circ} \mathrm{C}$ water. CTRL represents the effects of coadministration of capsaicin $100 \mu \mathrm{g}$ and orphanin FQ $30 \mu \mathrm{g}$ in the tail. J-113397 was co-administered with capsaicin and orphanin FQ in the tail. Asterisks represent a significant difference from CTRL $(* * P<.01)$. See Methods and Figure 2 for other details.
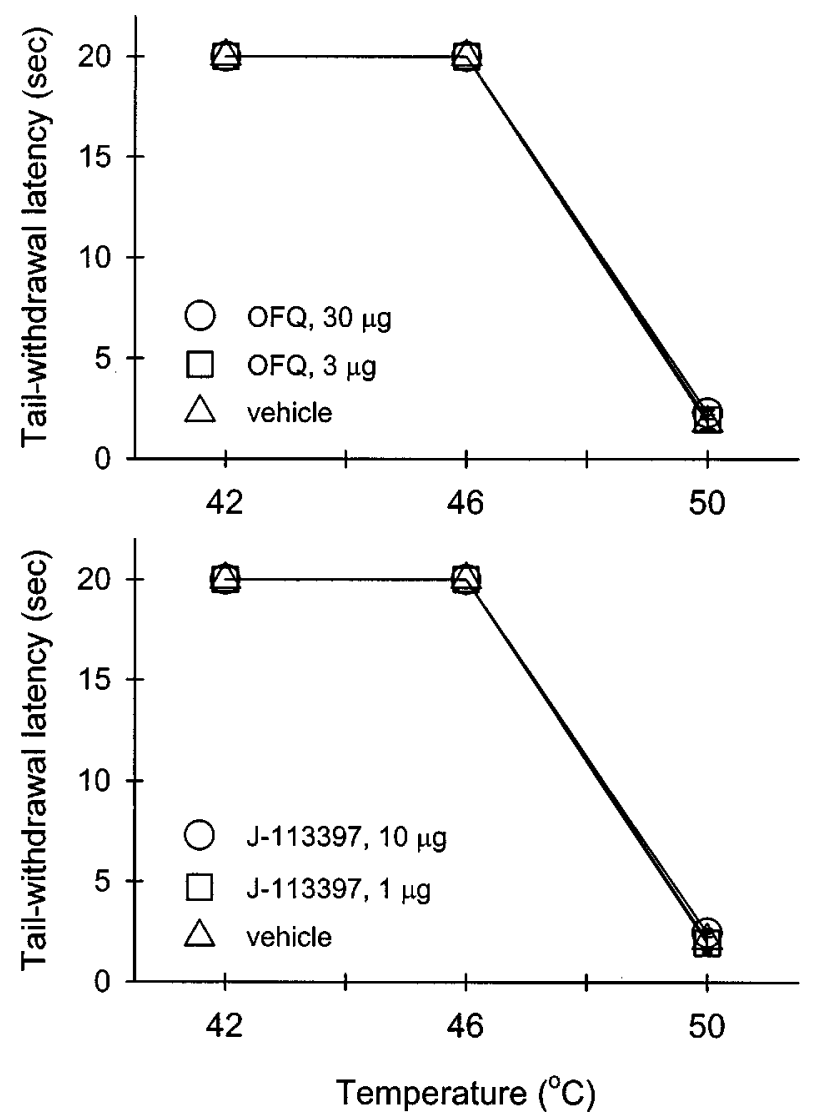

Figure 4 The thermal threshold of monkeys exposed to warm water in the absence and presence of either orphanin FQ or J-113397 in the tail. Open symbols represent tail-withdrawal latencies following s.c. administration of either orphanin FQ or J-113397 in the tail. Not all of the data are shown for the sake of clarity. See Methods and Results for other details. 
subcutaneously in the back, it did not antagonize the local action of OFQ. Figure 4 illustrates tail-withdrawal responses of naïve monkeys at $15 \mathrm{~min}$ following local injection in the tail. The injection procedure itself (i.e., vehicle injection) did not interfere with normal tail-withdrawal responses of monkeys. Although $50^{\circ} \mathrm{C}$ water alone is a noxious stimulus, s.c. administration of OFQ $30 \mu \mathrm{g}$ in the tail did not produce antinociception against $50^{\circ} \mathrm{C}$ water in this procedure (Figure 4, upper panel). Both OFQ $(1-30 \mu \mathrm{g})$ and $\mathrm{J}-113397(1-$ $10 \mu \mathrm{g})$ alone did not cause any swelling in the tail and both agents did not alter the thermal nociceptive threshold of naïve monkeys. In order to detect whether OFQ produces a dual action (i.e., both pronociception and antinociception) across a wide dose range, from $1 \mathrm{pg}$ to $1 \mu \mathrm{g}$ of OFQ was further tested alone in the monkey's tail. We did not find any changes of tail-withdrawal latencies in 42,46 and $50^{\circ} \mathrm{C}$ warm water following local injection of OFQ in the tail (data not shown). It should be noted that neither s.c. OFQ nor s.c. J113397 in the tail changed tail-withdrawal latencies through the entire test session (i.e., 5-60 min) after local injection.

Figure 5 illustrates the antagonist effect of different opioid receptor antagonists against OFQ-induced local attenuation of capsaicin-induced thermal nociception in $46^{\circ} \mathrm{C}$ water. The local antinociceptive action of OFQ was only antagonized significantly by $\mathrm{J}-113397(10 \mu \mathrm{g})$. Local administration of quadazocine $(32 \mu \mathrm{g}$, selective for $\mu \mathrm{OR})$, nor-BNI $(320 \mu \mathrm{g}$, selective for $\kappa \mathrm{OR})$, or naltrindole $(320 \mu \mathrm{g}$, selective for $\delta \mathrm{OR})$ was not effective in reversing the inhibitory action of OFQ in the periphery. On the other hand, Figure 6 illustrates the antagonist effect of J-113397 against different opioid receptor agonist-induced local actions. Local administration of DAMGO, a selective $\mu$ OR agonist, or U50488, a selective $\kappa \mathrm{OR}$ agonist, but not BW373U86, a selective $\delta \mathrm{OR}$ agonist, produced profound attenuation of capsaicin-induced thermal nociception. However, local administration of J-113397 $(10 \mu \mathrm{g})$ did not significantly antagonize the antinociceptive action mediated by either peripheral $\mu \mathrm{OR}$ or $\kappa \mathrm{OR}$.

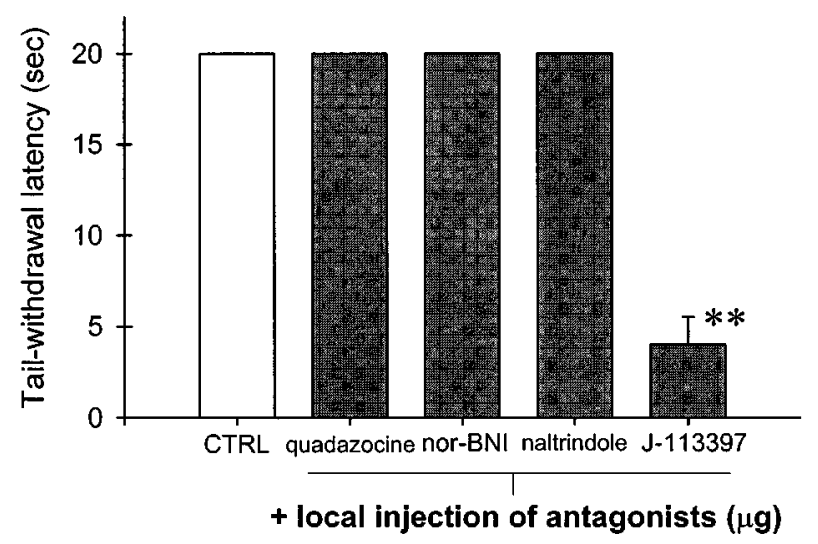

Figure 5 Selectivity of orphanin FQ-induced attenuation of capsaicin-induced thermal nociception in $46^{\circ} \mathrm{C}$ water. CTRL represents the effects of co-administration of capsaicin $100 \mu \mathrm{g}$ and orphanin FQ $30 \mu \mathrm{g}$ in the tail. Quadzocine $(32 \mu \mathrm{g})$, nor-binaltorphimine (nor-BNI, $320 \mu \mathrm{g})$, naltrindole $(320 \mu \mathrm{g})$, or $\mathrm{J}-113397(10 \mu \mathrm{g})$ was co-administered with capsaicin and orphanin FQ in the tail. Asterisks represent a significant difference from CTRL $(* * P<.01)$. See Methods and Figure 2 for other details.

\section{Discussion}

This study demonstrated that local administration of OFQ in the monkey's tail attenuated capsaicin-induced thermal nociception. OFQ-induced local antinociception was mediated by peripheral ORL1 receptors, independently of the classical opioid receptors. These data provide the first functional evidence of selective ORL1 receptor-mediated actions of OFQ in a primate species.

\section{Antinociceptive effects of orphanin $F Q$}

This study clearly shows that local administration of OFQ can dose-dependently inhibit capsaicin-induced thermal nociception in monkeys (Figure 2). The locally effective dose of OFQ, when applied in the back, did not inhibit capsaicininduced nociception. This indicates that the site of action of locally administered OFQ is located in the tail. Local administration of peptides can minimize the distribution factors and adverse effects produced by central or systemic administration. In particular, the site of action can be isolated and studied in the periphery. It has been shown that opioid peptides such as DAMGO and dynorphin-related analogues are only effective following local administration to attenuate capsaicin-induced nociception; and they are not effective following systemic administration even at doses up to 1000 -fold of locally effective doses. Such a large difference in potency is only observed with peptidic ligands, but not with non-peptidic compounds (Ko et al., 1998; 1999a; 2000).

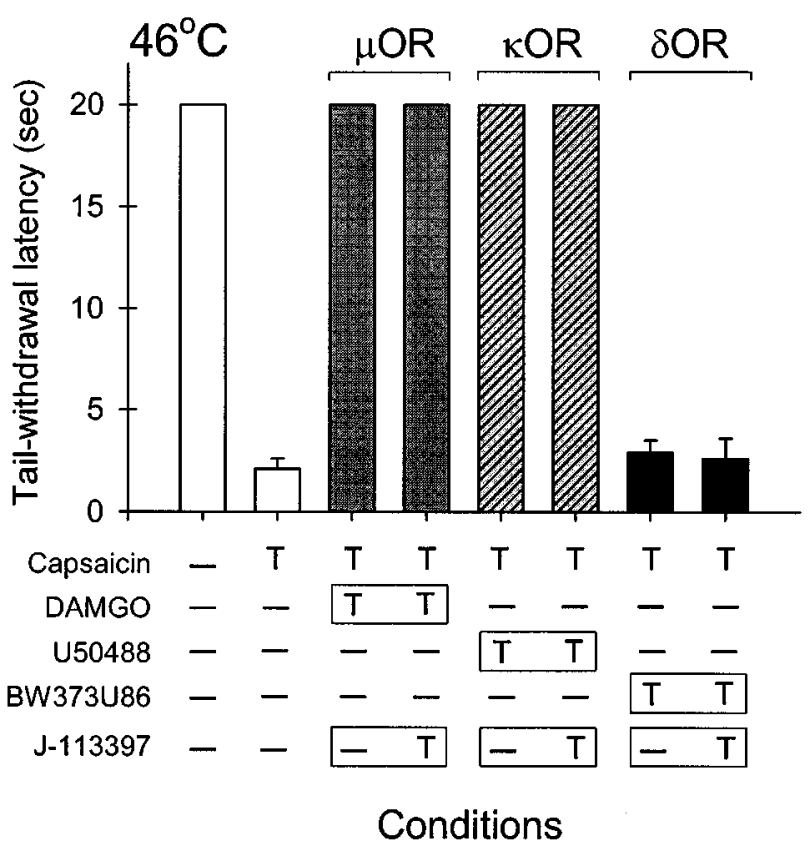

Figure 6 Lack of antagonism by J-113397 against classical opioid agonist-induced local attenuation of capsaicin-induced thermal nociception in $46^{\circ} \mathrm{C}$ water. The symbol ' $\mathrm{T}$ ' indicates the corresponding compound was administered subcutaneously in the tail. The symbol '-' indicates the corresponding compound was not given in the tail. Different shaded columns are paired to compare the antagonist effect of $\mathrm{J}-113397(10 \mu \mathrm{g})$ against the actions of $\mu \mathrm{OR}$ agonist (DAMGO, $32 \mu \mathrm{g}$ ), $\kappa \mathrm{OR}$ agonist (U50488, $100 \mu \mathrm{g}$ ), and $\delta \mathrm{OR}$ agonist (BW373U86, $320 \mu \mathrm{g}$ ), respectively. See Methods and Figure 2 for other details. 
These studies strengthen the notion that local application of peptidic ligands without untoward side effects may be a useful medication for localized painful conditions.

It should be noted that local administration of OFQ alone did not modify the thermal nociceptive threshold of the monkey's tail (Figure 4, upper panel). OFQ-induced local antinociception was only observed under the allodynia- or hyperalgesia-like state. This observation is similar to findings from our previous studies which characterized local antinociceptive actions of $\mu \mathrm{OR}$ and $\kappa \mathrm{OR}$ agonists against capsaicin (Ko et al., 1998; 1999a) and it is also similar to findings from rodent studies, in which the antinociceptive potency of opioid receptor agonists is enhanced on the peripheral terminals of nociceptive primary afferents innervating inflamed tissues (e.g., Stein et al., 1989; Nagasaka et al., 1996). There are several factors that may account for this phenomenon. For example, inflammation produces disruption of perineurial barriers, which leads to an easier access of opioid ligands to peripheral opioid receptors (Antonijevic et al., 1995). Opioid receptor agonists do not suppress the discharge of nociceptors in normal skin or their responses to noxious stimuli (Raja et al., 1986; Senami et al., 1986). Interestingly, Honore et al. (1996) have shown that intraplantar morphine depresses spinal c-Fos expression which is induced by carrageenan inflammation, but not by noxious heat. The ORL1 receptor may have a similar function as classical opioid receptors to modulate the activity of peripheral sensory fibers which are dynamically regulated by a variety of neuromediators following tissue injury and inflammation.

Capsaicin evokes pain sensation by activating the vanilloid receptor (VR1) and stimulating the release of neuropeptides such as SP and CGRP from primary afferent nociceptors (Winter et al., 1995; Caterina et al., 1997; Szallasi \& Blumberg, 1999). Activation of peripheral $\mu \mathrm{OR}, \kappa \mathrm{OR}$, or ORL1 receptors, but not $\delta \mathrm{OR}$, attenuates capsaicin-induced thermal nociception in monkeys (Ko et al., 1998; 1999a; and present study). This local antinociception against capsaicin can be explained by both inhibition of the excitability of sensitized nociceptors (Russell et al., 1987; Haley et al., 1990; Andreev et al., 1994) and inhibition of the release of SP and CGRP from peripheral sensory endings (Yonehara et al., 1992; Giuliani \& Maggi, 1996; 1997; Helyes et al., 1997). However, the rapid time course of capsaicin-induced thermal nociception may suggest that peripheral peptide release is not a major contributor to allodynia/hyperalgesia in this study and the nociception is due to the direct effect of capsaicin on the nerve terminals. Nevertheless, it would be important for further in vitro studies to compare the differential ability of $\mu \mathrm{OR}, \kappa \mathrm{OR}, \delta \mathrm{OR}$, and ORL1 receptors in a primate species in terms of inhibiting the discharge of primary afferent nociceptors and inhibiting the release of pronociceptive substances associated with neurogenic inflammation. Studies in mice lacking VR1 have demonstrated that VR1 is required for inflammatory sensitization to noxious thermal stimuli and VR1 is essential for tissue injury-induced thermal hyperalgesia (Caterina et al., 2000; Davis et al., 2000). Considering that capsaicin-sensitive nerve fibres are involved in a variety of nociceptive conditions (Barthó et al., 1990; Kim et al., 1995; Winter et al., 1995; Szallasi \& Blumberg, 1999), local administration of ORL1 receptor agonists may be effective for reducing pain derived from different nociceptive origins.

\section{Antagonism of peripheral ORL1 receptors}

Local administration of $\mathrm{J}-113397$, a selective ORL1 receptor antagonist, dose-dependently antagonized local antinociception of OFQ (Figure 3). In addition, a locally effective dose of J-113397, when administered subcutaneously in the back, did not antagonize the local action of OFQ. These antagonism studies confirm the site of action of locally administered OFQ, indicating that peripheral ORL1 receptors mediate local antinociception of OFQ against capsaicininduced thermal nociception. As noted, local administration of J-113397 alone did not modify the thermal nociceptive threshold of the monkey's tail (Figure 4, bottom panel). This may suggest that tonic activity of peripheral ORL1 receptors does not have a major role in modulating local nociceptive responses. Further studies utilizing systemic or central administration of ORL1 receptor antagonists, including insurmountable antagonists, will be necessary to determine the tonic activity of central ORL1 receptors.

Local administration of opioid receptor antagonists selective for $\mu \mathrm{OR}, \kappa \mathrm{OR}$, and $\delta \mathrm{OR}$ did not antagonize the local antinociceptive action of OFQ (Figure 5). This observation strongly supports that peripheral ORL1 receptors selectively mediate local antinociceptive effects of OFQ in this procedure. In addition, local administration of J-113397 did not antagonize the local antinociceptive actions of $\mu \mathrm{OR}$ and $\kappa \mathrm{OR}$ agonists in this procedure (Figure 6). It further confirms the antagonist selectivity of J-113397 on the ORL1 receptor (Ozaki et al., 2000; Hashiba et al., 2001). Taken together, these behavioral studies provide functional evidence that the ORL1 receptor, independent of classical opioid receptors, plays an important role in modulation of peripheral sensory nerves following tissue injury or inflammation.

\section{General summary}

This study clearly demonstrates that peripheral ORL1 receptors mediate OFQ-induced local antinociception against capsaicininduced thermal nociception in monkeys. More importantly, it provides a pharmacological basis for further studying the function of the ORL1 receptor in primates. The ORL1 receptor is widely distributed in the central and peripheral nervous systems and it may have very important roles in a variety of physiological functions (Henderson \& McKnight, 1997; Darland et al., 1998; Calo et al., 2000). Recently, a selective nonpeptidic ORL1 agonist, Ro 64-6198, has been developed (Dautzenberg et al., 2001). This non-peptidic ORL1 agonist can be further studied in monkeys in order to elucidate the potential antinociceptive function of the ORL1 receptor in primates. In particular, both intravenous and intrathecal administration routes are widely used for analgesic delivery in the clinic. Future studies characterizing and comparing the behavioral effects of i.v. and i.t. administration of OFQ and nonpeptidic ORL1 agonists in monkeys would provide a great deal of information for potential pain management in humans.

The authors would like to thank Kurt Willmont, Ryan Sherriff, and John Busenbark for excellent technical assistance. This study was supported by USPHS grants DA00254 (J.H. Woods) and DA13685 (M.C.H. Ko). 


\section{References}

ANDREEV, N., URBAN, L. \& DRAY, A. (1994). Opioids suppress spontaneous activity of polymodal nociceptors in rat paw skin induced by ultraviolet irradiation. Neuroscience, 58, 793-798.

ANTONIJEVIC, I., MOUSA, S.A., SCHAFER, M. \& STEIN, C. (1995). Perineurial defect and peripheral opioid analgesia in inflammation. J. Neurosci., 15, 165-172.

BARTHÓ, L., STEIN, C. \& HERZ, A. (1990). Involvement of capsaicinsensitive neurones in hyperalgesia and enhanced opioid antinociception in inflammation. Naunyn-Schmiedeberg's Arch. Pharmacol., 342, 666-670.

BUTELMAN, E.R., NEGUS, S.S., GATCH, M.B., CHANG, K.J. \& WOODS, J.H. (1995). BW373U86, a d-opioid receptor agonist, reverses bradykinin-induced thermal allodynia in rhesus monkeys. Eur. J. Pharmacol., 277, 285-287.

CALO, G., GUERRINI, R., RIZZI, A., SALVADORI, S. \& REGOLI, D (2000). Pharmacology of nociceptin and its receptor: a novel therapeutic target. Br. J. Pharmacol., 129, 1261-1283.

CATERINA, M.J., LEFFLER, A., MALMBERG, A.B., MARTIN, W.J., TRAFTON, J., PETERSEN-ZEITZ, K.R., KOLTZENBURG, M., BASBAUM, A.I. \& JULIUS, D. (2000). Impaired nociception and pain sensation in mice lacking the capsaicin receptor. Science, 288, 306-313.

CATERINA, M.J., SCHUMACHER, M.A., TOMINAGA, M., ROSEN, T.A., LEVINE, J.D. \& JULIUS, D. (1997). The capsaicin receptor: a heat-activated ion channel in the pain pathway. Nature, 389, $816-824$

CONNOR, M., YEO, A. \& HENDERSON, G. (1996). The effect of nociceptin on $\mathrm{Ca} 2+$ channel current and intracellular $\mathrm{Ca} 2+$ in the SH-SY5Y human neuroblastoma cell line. Br. J. Pharmacol., 118, 205-207.

DARLAND, T., HEINRICHER, M.M. \& GRANDY, D.K. (1998). Orphanin FQ/nociceptin: a role in pain and analgesia, but so much more. Trends Neurosci., 21, 215-221.

DAUTZENBERG, F.M., WICHMANN, J., HIGELIN, J., PY-LANG, G., KRATZEISEN, C., MALHERBE, P., KILPATRICK, G.J. \& JENCK, F. (2001). Pharmacological characterization of the novel nonpeptide orphanin FQ/nociceptin receptor agonist Ro 64-6198: rapid and reversible desensitization of the ORL1 receptor in vitro and lack of tolerance in vivo. J. Pharmacol. Exp. Ther., 298, 812-819.

DAVIS, J.B., GRAY, J., GUNTHORPE, M.J., HATCHER, J.P., DAVEY, P.T., OVEREND, P., HARRIES, M.H., LATCHAM, J., CLAPHAM, C., ATKinson, K., hughes, S.A., RANCE, K., GRAU, E., HARPER, A.J., PUGH, P.L., ROGERS, D.C., BINGHAM, S., RANDALL, A. \& SHEARDOWN, S.A. (2000). Vanilloid receptor1 is essential for inflammatory thermal hyperalgesia. Nature, $\mathbf{4 0 5}$, $183-187$.

EISENACH, J.C., HOOD, D.D., CURRY, R. \& TONG, C. (1997). Alfentanil, but not amitriptyline, redices pain, hyperalgesia, and allodynia from intradermal injection of capsaicin in humans. Anesthesiology, 86, $1279-1287$.

GIULIANI, S. \& MAGGI, C.A. (1996). Inhibition of tachykinin release from peripheral endings of sensory nerves by nociceptin, a novel opioid peptide. Br. J. Pharmacol., 118, 1567-1569.

GIULIANI, S. \& MAGGI, C.A. (1997). Prejunctional modulation by nociceptin of nerve-mediated inotropic responses in guinea-pig left atrium. Eur. J. Pharmacol., 332, 231-236.

HALEY, J., KeTCHUM, S. \& DICKENSON, A. (1990). Peripheral kopioid modulation of the formalin response: an electrophysiological study in the rat. Eur. J. Pharmacol., 191, 437-446.

HASHIBA, E., HARRISON, C., GALO, G., GUERRINI, R., ROWBOTHAM, D.J., SMITH, G. \& LAMBERT, D.G. (2001). Characterisation and comparison of novel ligands for the nociceptin/orphanin FQ receptor. Naunyn Schmiedebergs Arch Pharmacol., 363, 28 33.

HELYES, Z., NEMETH, J., PINTER, E. \& SZOlCSANYI, J. (1997). Inhibition by nociceptin of neurogenic inflammation and the release of SP and CGRP from sensory nerve terminals. $B r . J$. Pharmacol., 121, 613-615.

HENDERSON, G. \& MCKNIGHT, A.T. (1997). The orphan opioid receptor and its endogenous ligand-nociceptin/orphanin FQ. Trends Pharmacol. Sci., 18, 293-300.
HONORE, P., BURITOVA, J. \& BESSON, J.M. (1996). Intraplantar morphine depresses spinal c-Fos expression induced by carrageenin inflammation but not by noxious heat. Br. J. Pharmacol., 118, $671-680$.

JENNINGS, E.A. (2001). Postsynaptic K + current induced by nociceptin in medullary dorsal horn neurons. Neuroreport, 12, $645-648$.

KAWAMOTO, H., OZAKI, S., ITOH, Y., MIYAJI, M., ARAI, S., NAKASHIMA, H., KATO, T., OHTA, H. \& IWASAWA, Y. (1999). Discovery of the first potent and selective small molecule opioid receptor-like (ORL1) antagonist: 1-[(3R,4R)-1-cyclooctylmethyl-3- hydroxymethyl-4-piperidyl]-3-ethyl-1, 3-dihydro-2Hbenzimidazol-2-one (J-113397). J. Med. Chem., 42, 5061-5063.

KIM, Y.I., NA, H.S., HAN, J.S. \& HONG, S.K. (1995). Critical role of the capsaicin-sensitive nerve fibers in the development of the causalgic symptoms produced by transecting some but not all of the nerves innervating the rat tail. J. Neurosci., 15, 4133-4139.

KNOFLACH, F., REINSCHEID, R.K., CIVELLI, O. \& KEMP, J.A. (1996). Modulation of voltage-gated calcium channels by orphanin FQ in freshly dissociated hippocampal neurons. $J$. Neurosci., 16, 6657-6664.

KO, M.C., BUTELMAN, E.R. \& WOODS, J.H. (1998). The role of peripheral mu opioid receptors in the modulation of capsaicininduced thermal nociception in rhesus monkeys. J. Pharmacol. Exp. Ther., 286, $150-156$.

KO, M.C., BUTELMAN, E.R. \& WOODS, J.H. (1999a). Activation of peripheral kappa opioid receptors inhibits capsaicin- induced thermal nociception in rhesus monkeys. J. Pharmacol. Exp. Ther., 289, 378- 385 .

KO, M.C.H., JOHNSON, M.D., BUTELMAN, E.R., WILLMONT, K.J., MOSBERG, H.I. \& WOODS, J.H. (1999b). Intracisternal norbinaltorphimine distinguishes central and peripheral kappaopioid antinociception in rhesus monkeys. J. Pharmacol. Exp. Ther., 291, $1113-1120$.

KO, M.C.H., WILLMONT, K.J., BURRITT, A., HRUBY, V.J. \& WOODS, J.H. (2000). Local inhibitory effects of dynorphin A-(1-17) on capsaicin-induced thermal allodynia in rhesus monkeys. Eur. J. Pharmacol., 402, 69-76.

LAMOTTE, R.H., LUNDBERG, L.E.R. \& TOREBJORK, H.E. (1992). Pain, hyperalgesia and activity in nociceptive $\mathrm{C}$ units in humans after intradermal injection of capsaicin. J. Physiol., 448, 749764.

MEUNIER, J.-C., MOLlereaU, C., TOLL, L., SUAUdeAU, C., MOISAND, C., ALVINERIE, P., BUTOUR, J.-L., GUILLEMOT, J.C., FERRARA, P., MONSARRAT, B., MAZARGULL, H., VASSART, G., PARMENTIER, M. \& COSTENTIN, J. (1995). Isolation and structure of the endogenous agonist of opioid receptor-like ORL1 receptor. Nature, $377,532-535$.

MOLLEREAU, C., PARMENTIER, M., MAILLEUX, P., BUTOUR, J.L., MOISAND, C., CHALON, P., CAPUT, D., VASSART, G. \& MEUNIER, J.C. (1994). ORL1, a novel member of the opioid receptor family. Cloning, functional expression and localization. FEBS Lett., 341, 33-38.

NAGASAKA, H., AWAD, H. \& YAKSH, T.L. (1996). Peripheral and spinal actions of opioids in the blockade of the autonomic response evoked by compression of the inflamed knee joint. Anesthesiology, 85, 808-816.

OZAKI, S., KAWAMOTO, H., ITOH, Y., MIYAJI, M., AZUMA, T., ICHIKAWA, D., NAMBU, H., IGUCHI, T., IWASAWA, Y. \& OHTA, H. (2000). In vitro and in vivo pharmacological characterization of J-113397, a potent and selective non-peptidyl ORL1 receptor antagonist. Eur. J. Pharmacol., 402, 45-53.

RAJA, S.N., MEYER, R.A., CAMPBELL, J.N. \& KHAN, A.A. (1986). Narcotics do not alter the heat response of unmyelinated primary afferents in monkeys. Anesthesiology, 65, 468-473.

REINSCHEID, R.K., NOTHACKER, H.-P., BOURSON, A., ARDATI, A., HENNINGSEN, R.A., BUNZOW, J.R., GRANDY, D.K., LANGEN, H., MONSMA JR, F.J. \& CIVELLI, O. (1995). Orphanin FQ: A neuropeptide that activates an opioidlike $G$ protein-coupled receptor. Science, 270, $792-794$. 
RUSSELL, N.J.W., SCHAIBLE, H.-G. \& SCHMIDT, R.F. (1987). Opiates inhibit the discharges of fine afferent units from inflamed knee joint of the cat. Neurosci. Lett., 76, 107-112.

SENAMI, M., AOKI, M., KITAHATA, L.M., COLLINS, J.G., KUMETA, Y. \& MURATA, K. (1986). Lack of opiate effects on cat C ploymodal nociceptive fibers. Pain, 27, 81-90.

SIMONE, D.A., BAUMANN, T.K. \& LAMOTTE, R.H. (1989). Dosedependent pain and mechanical hyperalgesia in humans after intradermal injection of capsaicin. Pain, 38, 99-107.

STEIN, C., MILLAN, M.J., SHIPPENBERG, T.S., PETER, K. \& HERZ, A. (1989). Peripheral opioid receptors mediating antinociception in inflammation. Evidence for involvement of mu, delta and kappa receptors. J. Pharmacol. Exp. Ther., 248, 1269-1275.
SZALLASI, A. \& BLUMBERG, P.M. (1999). Vanilloid (Capsaicin) receptors and mechanisms. Pharmacol. Rev., 51, 159-212.

VAUGHAN, C.W. \& CHRISTIE, M.J. (1996). Increase by the ORLI receptor (opioid receptor-like1) ligand, nociceptin, of inwardly rectifying $\mathrm{K}$ conductance in dorsal raphe nucleus neurones. $\mathrm{Br}$. $J$. Pharmacol., 117, 1609-1611.

WINTER, J., BEVAN, S. \& CAMPBELL, E.A. (1995). Capsaicin and pain mechanisms. Br. J. Anaesth., 75, 157-168.

YONEHARA, N., IMAI, Y., CHEN, J.-Q., TAKIUCHI, S. \& INOKI, R. (1992). Influence of opioids on substance P release evoked by antidromic stimulation of primary afferent fibers in the hind instep of rats. Reg. Pept., 38, 13-22.

(Received September 7, 2001

Revised November 22, 2001 Accepted November 29, 2001) 